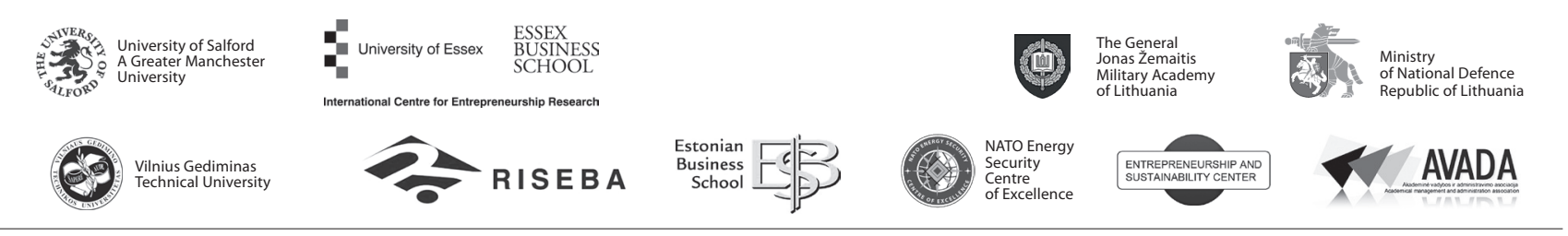

JOURNAL OF SECURITY AND SUSTAINABILITY ISSUES

ISSN 2029-7017 print/ISSN 2029-7025 online

2018 March Volume 7 Number 3

https://doi.org/10.9770/jssi.2018.7.3(2)

\title{
MIGRATION AS A FACTOR OF GERMANY`S SECURITY AND SUSTAINABILITY*
}

\author{
Peter Čajka ${ }^{1}$, Barbora Olejárová ${ }^{2}$, Andrea Čajková $^{3}$ \\ ${ }^{1,2}$ Matej Bel University, Kuzmányho 1, 97401 Banská Bystrica, Slovakia \\ ${ }^{3}$ Danubius University, Fučikova 269, 92521 Sládkovičovo, Slovakia \\ E-mails: ${ }^{1}$ peter.cajka@umb.sk, 2barbora.olejarova@umb.sk,3andrea.cajkova@vsdanubius.sk
}

Received 12 March 2017; accepted 14 February 2018

\begin{abstract}
With regard to its territorial size, economy and political power; Germany represents one of the most sustainable, competitive and economically developed Member States of the European Union. However, development of the knowledge-based economy on one hand and negative demographic trends on the other hand will force Germany to cover the growing demand for high-skilled labour force from non-EU countries in the coming years to keep this position. The paper analyses competitiveness within the framework of security and sustainability of the Federal Republic of Germany concerning labour migration from the third countries. Main research question of this article is formulated as follows: How can migration from the third countries influence economic development and competitiveness of Germany in terms of state's demographic problems? With regard to the above, we try to verify our hypothesis claiming that compensation of the domestic workforce through regulated migration flows - necessary because of declining and aging population and skill disharmony in Germany - is only a short-time solution of the current situation on the German labour market, but it is not sustainable in the long run.
\end{abstract}

Keywords: competitiveness, security, labour migration, sustainability, third countries, economic development, Germany

Reference to this paper should be made as follows: Čajka, P.; Olejárová, B.; Čajková, A. 2018. Migration as a factor of Germany's security and sustainability, Journal of Security and Sustainability Issues 7(3): 399-408.

https://doi.org/10.9770/jssi.2018.7.3(2)

JEL Classifications: F5, F22, J6, J11, J24, J31, J61

\section{Introduction}

When analysing the notion of competitiveness and sustainability, it is important to distinguish between the microeconomic and macroeconomic approach to this concept. From the microeconomic perspective, competitiveness is defined as the ability of a company or organisation to compete, grow, and be productive in a market economy. However, there is no single definition of macroeconomic competitiveness on the level of nation states (Martin 2004; Guseva et al. 2017; Andreeva et al. 2017). In the Global Competitiveness Report, the World Economic Forum defines competitiveness as "the set of institutions, policies and factors that determine the level of productivity of a country" (WEF 2009, p. 4). On the other hand, the Organisation for Economic Co-operation and Development (OECD) sees national competitiveness as the "the degree to which a nation can, under free trade and fair market conditions, produce goods and services which meet the test of international markets, while

* This article is published within a research project VEGA 1/0783/16 and VEIGA 6/2017 
simultaneously maintaining and expanding the real income of its people over the long-term" (OECD 1992). The inconsistent definitions of macroeconomic and regional competitiveness may incur problems, which are pointed out by various authors (Hlushko et al. 2015; Astakhova et al. 2016; Chmielewska, Horváthová 2016; Andreeva et al. 2016; Bonatti 2017; Lisin et al. 2017; Torój 2017; Kuzmin 2017). For example, Krugman (1994) emphasises that on the level of companies we speak of a zero-sum game, i.e. the gain of one party automatically lead to the loss of another; whereas on the national level, the success of a certain state or region creates rather than thwarts opportunities for the others.

Since there is no single definition of national competitiveness, neither are there accurate indicators which could be used to compare the competitiveness of individual countries. Listed among the most relevant sources which compare the competitiveness of particular states are the Global Competitiveness Report mentioned above (WEF) and the World Competitiveness Yearbook (International Institute for management Development, IMD). Apart from these, the European Union draws annual comparisons of its member states' competitiveness. The WEF compares 114 indicators grouped into 12 pillars: institutions, infrastructure, macroeconomic environment, health and primary education, higher education and training, goods market efficiency, labour market efficiency, financial market development, technological readiness, market size, business sophistication, and innovation. (WEF 2017) IMD grouped different aspects of competitiveness into 4 groups: economic performance, government efficiency, business efficiency and infrastructure. When analysing competitiveness, OECD centres on five indicators which, besides the use of information and communication technologies, include also the innovation and diffusion of technology, human capital, support given to business, and the macroeconomic stability as a whole (Martin 2004).

What all sources agree upon is that the human factor is an important influence on the country's competitiveness, in the following two areas in particular:

1. Maintaining balance between highly skilled and qualified workforce and those with few qualifications, in response to labour market needs; the country' competitiveness is influenced by its ability to train a qualified and talented workforce, which contributes to the country's development of innovations and technological progress (Destatis 2015; WEF 2015; Ehrenberger et al., 2015). However, the significance of the low-skilled workers is often underestimated; they, too, contribute equally to the country's economy as it is not possible for everybody to work in the ICT sector.

2. Maintaining stable age distribution, which is important for the country's economic growth; population aging is not only connected to problems such as burdening the country's social system in terms of healthcare and retirement pension, but also to the lack of workforce which generates profit and maintains the existing standard of living in the particular country. The relation between the non-working population and the potential workforce is expressed by the old-age dependency ratio (ODR) ${ }^{2}$ and the potential support ratio (PSR), ${ }^{3}$ which enable empirical comparison of age distribution in individual countries. In general, the higher the ODR is, the lower the PSR, hence labour productivity is likewise lower and thus competitiveness too.

If a country's native population fails to fully meet the demand for human capital, often the lack of human resources is counterbalanced by controlled migration flows, which can, in the short-term, reduce the deficit.

\footnotetext{
2 ODR stands for "old-age dependency ratio." The total dependency ratio expresses the number of children aged 0-14 and persons older than 65 per 100 people economically active. The dependency ratio can be decomposed into youth dependency ratio (regarding children up to the age of 14) and the aforementioned old-age dependency ratio (regarding persons in their retirement age) (Coleman 2001).

3 PSR stands for "potential support ratio", which expresses the number of economically active people per one person over 65 years of age (Workie Tiruneh et al. 2012).
} 


\section{Using migration as means for maintaining the level of competitiveness in Germany}

As can be seen from Table 1, all the scales of competitiveness which were mentioned above list Germany on the top ranks. What remains unanswered though is whether this growth is caused by the migration from third countries; whether Germany actually needs this migration in order to maintain its competitiveness. Migration is, of course, a very hotly-debated topic which is mostly fuelled by the mass media which shape up today's public opinion (Čábelková et al. 2015; Lincényi 2017; Pavlova, Šenfelde 2017).

Table 1: Germany's rank based on statistics which compare competitiveness of the world's nations in the last three years.

\begin{tabular}{|l|c|c|c|}
\hline \multirow{2}{*}{} & \multicolumn{3}{|c|}{ YEAR } \\
\cline { 2 - 4 } & $\mathbf{2 0 1 5}$ & $\mathbf{2 0 1 6}$ & $\mathbf{2 0 1 7}$ \\
\hline World Competitiveness Yearbook (IMD) & 10 & 12 & 13 \\
\hline The Global Competitiveness Report (WEF) & 4 & 4 & 5 \\
\hline
\end{tabular}

Source: Based on the data from IMD (2015), IMD (2017), WEF (2015), and WEF (2017).

The following part of the paper presents factors connected to human resources which can adversely influence Germany's competitiveness and at the same time the paper offers possible solutions, in which migration could be a helpful factor (Focus Migration 2005):

1. Qualifications mismatch between the market needs and the worker's qualification. Germany has been lately experiencing a decline in employment in the agricultural and manufacturing sectors, while in the service sector, labour demand is growing still. This phenomenon is typical for all developed countries, being a result of the delocalisation of labour intensive production into areas with cheaper labour force, Asia in particular; while high-skilled jobs are likely to grow in number in member states of the OECD, mainly because of the availability of a suitably educated workforce with language skills (Čajka et al. 2014). Therefore, the demand for highlyqualified workforce in Germany will grow, especially in areas such as financial services and the ICT sector; well-qualified immigrants can meet this growing demand.

2. Preferences mismatch occurs when native workers do have the required qualifications, but are not willing to do particular jobs, either because of inadequate pay, high physical demands or low social status. This problem, too, can be solved through migration, immigrants being often hired to do the so-called 3D jobs. ${ }^{4}$

3. Regional mismatch occurs when native workers do have the required qualifications, are willing to do the job, but are not ready to move to a different region in pursuit of work. This particular aspect can be disregarded when speaking of Germany, considering the statistics showing inter-regional mobility in Germany. When monitoring the number of migrant workers, who are defined as individuals working in a different German state than is their state of residence, it can be noted that the number of such individuals roughly rose by $27.9 \%$ between 2004 and $2014 .{ }^{5}$

\footnotetext{
4 Interpretation can differ according to the source, but the "3Ds" usually stand for "dirty, dangerous, and demanding/demeaning/difficult."

5 In this particular point, migration between the states of Germany is analysed, i.e. migration between the first-level NUTS (Nomenclature of Territorial Units for Statistics in EU).
} 
Table 2: The number of employees who have social security in a different federal state than is their state of residence (2004-2014)

\begin{tabular}{|c|c|c|c|}
\hline State (Bundesland) & Residence in other state (2004) & Residence in other state (2014) & Increase in \% \\
\hline Schleswig-Holstein & 96,390 & 119,053 & +23.5 \\
\hline Hamburg & 266,982 & 333,805 & +25.0 \\
\hline Lower Saxony & 200,758 & 261,463 & +30.2 \\
\hline Bremen & 112,472 & 128,369 & +14.1 \\
\hline North Rhine-Westphalia & 296,646 & 364,017 & +22.7 \\
\hline Hesse & 285,974 & 339,932 & +18.9 \\
\hline Rhineland-Palatinate & 117,129 & 158,743 & +35.5 \\
\hline Baden-Württemberg & 299,592 & 368,149 & +22.9 \\
\hline Bavaria & 247,803 & 324,674 & +31.0 \\
\hline Saarland & 52,545 & 55,538 & +5.7 \\
\hline Berlin & 195,398 & 283,075 & +44.9 \\
\hline Brandenburg & 91,172 & 129,715 & +42.3 \\
\hline Mecklenburg-Vorpommern & 19,143 & 26,667 & +39.3 \\
\hline Saxony & 70,810 & 100,691 & +42.2 \\
\hline Saxony-Anhalt & 47,692 & 67,463 & +41.5 \\
\hline Thuringia & 42,124 & 62,570 & +48.5 \\
\hline Total & $2,442,630$ & $3,123,924$ & +27.9 \\
\hline
\end{tabular}

Source: Based on the data from DGB (2016)

Mismatch due to information deficits is caused by the lack of information on existing vacancies.

4. Demographic mismatch is rooted in population ageing ${ }^{6}$ as well as population decline. Lower birth rate, population ageing, the possibility of population decline and hence a decline in potential workforce are all concepts often linked to the fall in GDP. It is thanks to migration that the number of inhabitants increased between 1972 and 2014 from 78.8 million to 80 million, resulting also in the increase among the people who are economically active; currently the working-age population is 49.2 million people ${ }^{7}$ (Destatis 2015). The demographic change is expected, however, to lead to a significant decrease of the working-age population by 2020. Within a few years from now the large birth cohorts form the 1950s and the 1960s will reach retirement-age. Therefore, it is important to take measures nowadays in order to guarantee qualified workforce in the years to come. Migration is one way to solve the demographic problems in Germany, yet it is no more than a short-term solution. A detailed analysis of these issues was conducted by the Population Division of the United Nations in 2001, titled "Replacement Migration: Is It a Solution to Declining and Ageing Populations?" It explores the possible solutions offered by migration which could help slow down and prevent depopulation as well as the decrease of the working-age population and maintain the same old-age dependency ratio (Coleman 2001). Table 3 shows that in order to maintain the size of a population between 15 and 64 years old, the net migration rate would have to be 487000 immigrants per year, whereas to maintain the same PSR as it was in 1995 the annual net migration rate would have to be over 3.6 million people, which is not realistic. Besides, such numbers would generate new problems, on both the cultural and security levels. Therefore, migration is really only a short-term solution to the problem of the demographic deficit (Fiedle, Grünheid 2013; BPB 2015; Strielkowski et al. 2016; Strielkowski et al. 2017).

6 There are two factors that cause population ageing - the decline in fertility and the rising life-expectancy.

7 Data gathered in 2013 
Table 3. Population prognosis in Germany depending on the migration flow by $2050^{8}$

\begin{tabular}{|c|c|c|c|}
\hline & $\mathbf{1 9 9 5}$ & $\begin{array}{c}\text { SCENARIO A } \\
\text { Constant size of an age group } \\
\mathbf{1 5 - 6 4}(\mathbf{2 0 5 0 )}\end{array}$ & $\begin{array}{c}\text { SCENARIO B } \\
\text { Constant } \\
\text { PSR (2050) }\end{array}$ \\
\hline NET MIGRATION RATE & & 487,000 & $3,630,000$ \\
\hline TOTAL POPULATION & 240,000 & $92,000,000$ & $299,000,000$ \\
\hline AGE GROUP 15-64 & $81,600,000$ & $\mathbf{5 5 , 7 0 0 , 0 0 0}$ & $199,400,000$ \\
\hline AGE GROUP 65+ & $\mathbf{5 5 , 7 0 0 , 0 0 0}$ & $22,800,000$ & $45,178,000$ \\
\hline PSR & $12,600,000$ & 2.44 & $\mathbf{4 . 4 1}$ \\
\hline
\end{tabular}

Note: Scenario A - the goal is to maintain a constant age group 15-64 with regard to 1995; Scenario B - the goal is to maintain constant PSR with regard to 1995.

Source: UN (2001).

\section{Third-country migration to Germany in the past and present}

Germany has a rather long experience with using labour migration to improve the country's competitiveness. Regarding the reconstruction after World War II, Germany experienced rapid economic growth, which meant that labour productivity was improving, and unemployment was decreasing. ${ }^{9}$ Whereas unemployment in the 1950 s averaged $15 \%$ across the country, in 1962 it fell only to $0.7 \%$ which is historically the lowest unemployment rate Germany has ever had (Destatis 2017b, BMF 2005). Trying to maintain the steady economic growth, the government signed a series of international agreements with both European and non-European countries which facilitated labour migration to Germany; in 1955 they signed an agreement with Italy, in 1960 with Spain and Greece, in 1961 with Turkey, in 1963 with Morocco, in 1964 with Portugal, in 1965 with Tunisia, and in 1968 with Yugoslavia ${ }^{10}$ (Münz, Ulrich 1998; Glazar, Strielkowski 2010). Unlike today, when foreign workers are often chosen due to their skills and qualifications, foreign workers back then were generally employed in low-skilled positions which were not particularly attractive to the Germans themselves. With foreign workforce who would fill these positions, Germans could move up to more jobs in professional sectors, which enhanced the economic growth of the country and in consequence its competitiveness as well, which is also true for other countries (Domid 2015; Bilan, Strielkowski 2016). Friedrich Heckman, a German sociologist whose main field of interest are migration studies, asserts that between the year 1960 and 1970, as much as 2.3 million native workers transformed from blue-collar to white-collar workers ${ }^{11}$ (Heckmann 1981). A similar model was adopted in the German Democratic Republic, whose response to the labour shortage in the 1970s was to recruit foreign workers from other socialist countries from Central and Eastern Europe, later from Cuba, Mozambique, and Vietnam. The main difference was in the length of the job placement; while GDR was rather strict about the rotation of labour migrants after a set period of time, Germany often allowed the migrants to extend their work permits for a period which exceeded the one year originally agreed upon ${ }^{12}$. As a consequence, the number of labour migrants in GDR never exceeded 200 000, whereas in Germany, the year 1973 set the record for the highest number of foreign workers - that being no less than 2.3 million. It is not without interest to draw a parallel between the past and presence. Between 1968 and 1973 the number of foreign migrants swarming into Germany was some five hundred to thousand every day and sometimes additional airplanes and trains had to be employed to transport all these workers into the country (Münz, Ulrich 1998). Nowadays it is not much different with the migration flow from Middle-East and Sub-Saharan Africa in search of asylum and work.

\footnotetext{
8 It is defines as the positive difference between the number of immigrants and the number of emigrants in a certain area; i.e. population growth through migration (Jurčová 2005).

9 If not stated otherwise, when using the term "Germany" in historical context, the paper refers to the German Federal Republic and not the German Democratic Republic.

${ }^{10}$ Foreign workers were accepted in Germany as long as 1973, when on 23rd November they imposed a recruitment ban which completely prevented hiring labour force from outside EEC (Domid 2015).

11 In other words, they switched from manual labour to administrative work.

12 In 1971 the restrictions on the renewal of work permits were loosened. Having worked in Germany for at least five years, labour migrants could extend work permits for another five years (Münz, Ulrich 1998).
} 
Currently, there are two ways of recruiting workforce in Germany, with the objective of maintaining the current level of the country's competitiveness. First, it is accepting asylum seekers who can be regarded as cheap workforce suitable for low-skilled positions; and secondly, it is negotiating agreements with third countries in order to recruit high-skilled and qualified workers who would be employed in services, ICT sectors, finances, healthcare, etc. In 2016, there was 18.6 million persons with a migration background, living in Germany. Migration background is not determined solely according to the citizenship, but also according to nationality and origin of the person's parents. The group of people with migration background „consists of all persons who have immigrated into the territory of today's Federal Republic of Germany after 1949, and of all foreigners born in Germany and all persons born in Germany who have at least one parent who immigrated into the country or was born as a foreigner in Germany" (Destatis 2017c). Over 7 million of them still have an immigrant status, whereas the remaining 8 million were granted German citizenship by naturalisation, or they are in the process of repatriation; among the latter the largest group are immigrants from Turkey ( 2.5 million) and from former Yugoslavia (1.5 million) (Destatis 2017c). (Figure 1)

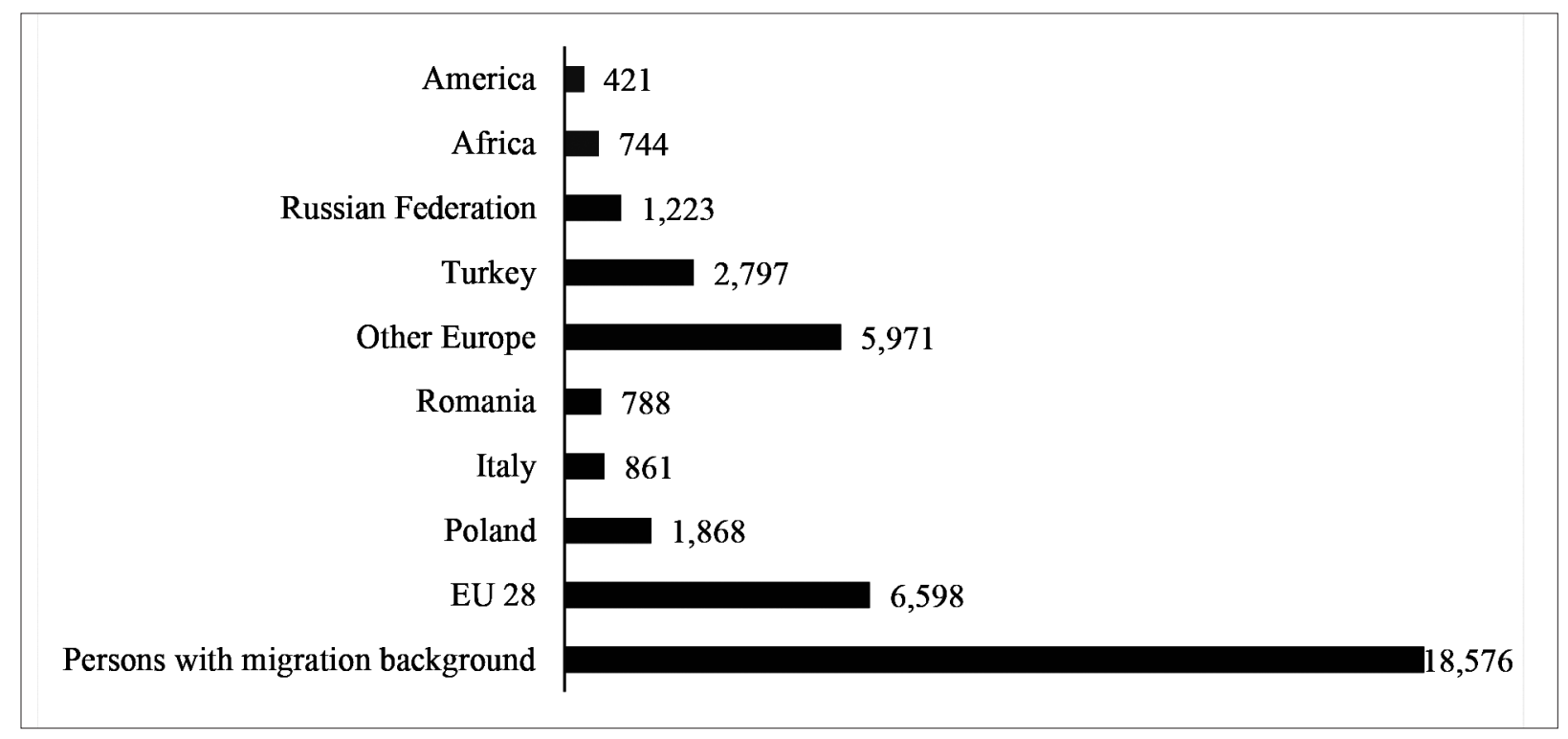

Figure 1. Persons with migration background in Germany according to continents and most common countries of origin (in thousands)

Source: Based on the data from Destatis (2017)

Whereas nationals of EEA member states including Switzerland ${ }^{13}$ can settle in any EU member state with equal employment rights as the state's citizens, third-country nationals need residence permit in order to become a proper employee. In 2005 the Immigration Act was passed in Germany, which established a general legal framework defining all aspects of immigration policy. The catalyst behind its adoption was the realisation that the decline in fertility and population ageing pose a danger to the social security system (especially when taxation comes into the view (see e.g. Čábelková and Strielkowski 2013) and harm the state's economy. It included strategies for attracting highly qualified immigrants, emphasised the importance of making the integration more effective, and pressed for asylum reform and the simplification of the procedures for expelling foreigners who pose a potential threat to the country (First German Immigration... 2005). Yet another key document in Germany is the Act on the Residence, Economic Activity and Integration of Foreigners in the Federal Territory (2008). In order to identify and manage labour demand, Germany applies a number of tools and approaches. The most important ones include:

13 The European Economic Area (EEA) unites the EU Member States and the three EEA EFTA States (Iceland, Liechtenstein, and Norway) into an Internal Market governed by the same basic rules. These rules aim to enable goods, services, capital, and persons to move freely about the EEA in an open and competitive environment, a concept referred to as the four freedoms. Since 1st January 1014, Bulgarians and Rumanians have also the right to the free movement of workers. Croatia is still in the period of transitional measures, which restricts Croatian citizens from the German labour market. 
1. Occupation lists (Positivliste / Whitelist pursuant to section 6 para. 2 sentence 1 no. 2 of the Employment Regulation: Immigration into recognized occupations) are lists of labour shortages in the country compiled by The Federal Ministry for Labour and Social Affairs (BMAS) and The Federal Employment Agency (BA) following skilled workers bottleneck analysis of the German labour market, which is updated every six months. The occupation lists relate only to skilled workers (qualification level 2) and specialists (qualification level 3). The last one was issued in July 2017 (Bundesagentur für Arbeit 2017b).

2. International agreements regulating engagement in an occupation - concluded with third countries for the purpose of labour migration. Foreign workers can be admitted as contract workers or guest workers. Contract workers agreements are concluded between Germany and the countries Bosnia-Herzegovina, Macedonia, Serbia, and Turkey on the posting and employment of employees of foreign companies based on work contracts. On the other hand, "guest workers are individuals that have already acquired a professional qualification in their home country, that have some knowledge of German and that take up employment in Germany to improve their professional and language skills (maximum duration: 18 months). This is based on bilateral agreements with Albania and the Russian Federation” (Bundesagentur für Arbeit 2017a, p15).

Moreover, the migration crisis of people from the Middle East that followed the outbreak of the Syrian Civil War in 2011 also influenced German policy of employing third-country nationals significantly. In 2016, there were 745,545 asylum applicants registered in Germany and the refugee population of the country in 2016 was 669,408 people (World Bank 2017; AIDA 2017). Most of them came from Syria, followed by Albania, Kosovo, Afghanistan, Iraq, Serbia, and Eritrea. In 2015, 71.1\% of asylum seekers were under 30 and more than two thirds of them were men. Although there is no representative data on the qualification of these asylum seekers, the estimated numbers indicate that about $20 \%$ of them have professional education and about 30 to $40 \%$ of them have at least one year long practical work experience, which can be adapted to the German labour market (Martín 2016). These people could help fill qualitative and quantitative labour shortages in Germany; yet, the employment rate of refugees is generally lower compared to the native population especially in the first years. A study of the German Socio-Economic Panel found "that a number of years ago only 8\% of refugees gained regular employment within the first year of stay in Germany, 50\% within 5 years, $60 \%$ within 10 years and $75 \%$ within 15 years" (Martín 2016, p29). To speed up this process, in 2014 the government reduced the employment ban on asylum seekers to three months, so that their integration to the labour market can start even before they are granted asylum. Another federal activities designed to hasten refugees' labour market integration include 2014-2015 "Early Intervention" project or programme of the Federal Employment Agency "Perspectives for Refugees".

\section{Conclusions}

An increase in the importance of knowledge-based economy will bring about growing demand for highly qualified workforce, which, however, Germany will probably not be able to fulfil with native workforce alone, considering the decline in population, population ageing, and qualification mismatch despite increasing interregional mobility. This situation would lead to stagnation and bring down the country's competitiveness, which would inevitably lower the standard of living.

Based on the country's historical experience with recruiting manpower after World War II, it can be agreed upon that migration is a solution to the problem in the short-term. In the years 1955-1973 labour migration helped Germany revive their economy to the extent that nowadays it ranks among the most competitive countries of the EU. However, some of the side effects included political turmoil, problems with the integration of immigrants, and the ill will of the native population, who consider third-country immigration as the cause of wage fall and see the immigrants steeling their jobs. It was hinted above that with controlled migration this is not the case; on the contrary, highly qualified migrants are treated the same way as native workforce is, whereas lowskilled immigrants will do the 3D jobs, which Germans do not find attractive anyway; this enables the native population to get involved with more profitable economic sectors. Nowadays, Germany copies the model of accepting labour migrants which was developed in 1955 under completely different circumstances. While the 
labour migration after World War II was caused by the economic growth, which Germany wanted to maintain, thus filling the vacancies, nowadays labour migration is supposed to prevent Germany's economic recession. The analyses worked out by the UN imply that in order to maintain a stable age distribution, the net migration rate would have to be 3.6 million people per year, which is not realistic. If Germany attempts to use migration as means to maintain their competitiveness, it should be aware that an extensive ethnic change is inevitable and that security issues might be at play. A possible solution would be accepting immigrants for no longer than a specific period of time, requiring them to return to their own countries after the time will have passed; this, however, would be possible only in the case of migrants who came pursuant to a contract agreement. It is not an option in the case of asylum seekers who are accepted as potential cheap workforce, having migrated because of the migration crises in Africa and the Middle East.

\section{Acknowledgements}

This article is published within a research project VEGA 1/0783/16 and VEIGA 6/2017

\section{References}

AIDA. 2017. Statistics Germany. Asylum Information Database.

Andreeva, E. L.; Karkh, D. A.; Myslyakova, Y. 2017. Conceptual Approach to Forming the Basic Code of Neo-Industrial Development of a Region. Economy of Region 13(3): 732-745. https://doi.org/10.17059/2017-3-8

Andreeva, E. L.; Simon, H.; Karkh, D.A.; Glukhikh, P.L. 2016. Innovative entrepreneurship: a source of economic growth in the region. Economy of Region 12(3): 899-910. https://doi.org/10.17059/2016-3-24

Astakhova, E. A.; Chuprova, D. B.; Kalyugina, S. N.; Pyanov, A. I. 2016. Strategy of Inclusion of Reproductive Work in the Social Production. International Journal of Environmental and Science Education 11(11): 4631-4638.

Bilan, Y.; Strielkowski, W. 2016. Migration in post-transition economies: immigration surplus in Visegrad group countries. International Journal of Trade and Global Markets 9(2):182-196. https://doi.org/10.1504/IJTGM.2016.076310

BMF. 2005. The Impact of Immigration on Germany's Society. Germany: Federal Office for Migration and Refugee.

Bonatti, L. 2017. Anemic Economic Growth in Advanced Economies: Structural Factors and the Impotence of Expansionary Macroeconomic Policies. Rivista internazionale di scienze sociali 2(2):131-172.

BPB. 2015. Demografischer Wandel in Deutschland. Bundeszentrale für politische Bildung.

Bundesagentur Fur Arbeit. 2017a. Employment of Foreign Workers in Germany. Bundesagentur für Arbeit.

Bundesagentur Fur Arbeit. 2017b. White List. Immigration into Recognized Occupations. Bundesagentur für Arbeit.

Čábelková, I.; Strielkowski, W.; Mirvald, M. 2015. Business influence on the mass media: a case study of 21 countries. Transformation in Business and Economics 14(1): 65-75

Čábelková, I.; Strielkowski, W. 2013. Is the level of taxation a product of culture? A cultural economics approach. Society and Economy 35(4): 513-529. https://doi.org/10.1556/SocEc.2013.0007

Čajka, P.; Jaroszewicz, M.; Strielkowski, W. 2014. Migration Incentives and Flows between Belarus, Moldova, Ukraine and the European Union: a Forecasting Model. Economics and Sociology 7(4): 11-25. https://doi.org/10.14254/2071-789X.2014/7-4/1

Chmielewska B.; Horváthová Z. 2016. Policy levelling economic and social inequalities between rural and urban areas. Journal of International Studies 9(2): 103-111. https://doi.org/10.14254/2071-8330.2016/9-2/7

Coleman, D. A. 2001. 'Replacement Migration', or why Everyone's going to have to live in Korea. A Fable for our Times from the United Nations. University of Oxford.

DESTATIS. 2015. Germany's Population by 2060. Results of the 13th Coordinated Migration Projection. Destatis - Federal Statistical Office of Germany.

DESTATIS. 2017a. Bevölkerung und Erwerbstätigkeit. Bevölkerung mit Migrationshintergrund - Ergebnisse des Mikrozensus 2016. Destatis - Federal Statistical Office of Germany. 
DESTATIS. 2017b. Labour Market. Statistisches Bundesamt.

DESTATIS. 2017c. Migration and Integration. Destatis - Federal Statistical Office of Germany.

DGB. 2016. Mobilität in der Arbeitswelt: Immer mehr Pendler, immer größere Distanzen. Deutscher Gewerkschaftsbund.

DOMID. 2015. Migration History in Germany. Documentation Center and Museum of Migration in Germany.

Ehrenberger, M.; Koudelkova, P; Strielkowski, W. 2015. Factors influencing innovation in small and medium enterprises in the Czech Republic. Periodica Polytechnica. Social and Management Sciences 23(2): 73-83. http://dx.doi.org/10.3311/PPso.7737

Fiedle, CH; Grunheid, E. 2013. Bevölkerungsentwicklung, Daten, Fakten, Trends zum demografischen Wandel. Wiesbaden: Bundesinstitut für Bevölkerungsforschung.

Deutsche Welle. 2005. First German Immigration Law Takes Effect. Deutsche Welle.

Focus Migration. 2005. Does Germany need Labour Migration? Das Hamburgische WeltWirtschaftsInstitut - Focus MIGRATION.

Glazar, O.; Strielkowski, W. 2010. Turkey and the European Union: possible incidence of the EU accession on migration flows. Prague Economic Papers 19(3): 218-235. https://doi.org/10.18267/j.pep.373

Guseva, V.E.; Ungureanu, L.; Kuzmin, E.A. 2017. Mathematical Models of Uncertainty in Economics. Journal of Applied Economic Sciences, Volume XII, Summer 3(49): 753- 765.

Heckmann, F. 1981.Die Bundesrepublik, ein Einwanderungsland? : zur Soziologie der Gastarbeiterbevölkerungals Einwandererminorität. Stuttgart: Klett-Cotta.

Hlushko, O.; Gryshova, I.; Shcherbata, M. 2015. Enterprises` economic sustainability assessment on the basis of performance indicators. Economic Annals-XXI 155(11-12):82-86.

IMD. 2015. The World Competitiveness Scoreboard 2015. International Institute for Management Development.

IMD. 2017. The World Competitiveness Ranking - One Year Change. International Institute for Management Development.

Lincényi, M. 2017. Entrepreneurship ecosystem facets: the European migrant crisis and public opinion in Slovakia, Entrepreneurship and Sustainability Issues 5(2): 357-367. https://doi.org/10.9770/jesi.2017.5.2(14)

Jurčová, D. 2005. Slovník demografických pojmov. Infostat - Institute of Informatics and Statistics.

Krugman, P. 1994. Competitiveness: A Dangerous Obsession. Foreign Affairs 73(2): 28-44

Kuzmin, E. 2017. A Study on the Problems of the Structure of Transaction Costs. Problems and Perspectives of Management 15(3): 224-233. https://doi.org/10.21511/ppm.15(3-1).2017.06

Lisin, E.; Kindra, V.; Horvathova, Z. 2017. Sustainable development of regional heat supply systems in the context of the Eurasian Economic Union energy markets association. Journal of Security and Sustainability Issues 6(4):745-760. http://doi.org/10.9770/ jssi.2017.6.4(18)

Martin, R. L. 2004. A Study on the Factors of Regional Competitiveness. University of Oxford.

Martín, I. et. al. 2016. From Refugees to Workers Mapping Labour-Market Integration Support Measures for Asylum Seekers and Refugees in EU Member States Volume I: Comparative Analysis and Policy Findings. Bertelsmann Stiftung.

Munz, R.; Ulrich, R. E. 1998. Changing Patterns of Immigration to Germany, 1945-1997. Migration Dialogue, UC Davis.

Pavlova, I.; Šenfelde, M. 2017. The impact on the population on the sustainable urban economic development, Entrepreneurship and Sustainability Issues 5(2): 330-344. https://doi.org/10.9770/jesi.2017.5.2(12)

Porvazník, J.; Ljudvigová, I. 2016. General theory of systems, cybernetics and evaluation of human competence by solving present crisis problems of civilisation. Procedia - Social and Behavioural Sciences 230: 112-120. https://doi.org/10.1016/j.sbspro.2016.09.014

OECD. 1992. Technology and the Economy - the Key Relationships. OECD

Strielkowski, W.; Šperková, L.; Jacek, B. 2017. Migration and Remittances Nexus: Economic Implications and Analysis. Amfiteatru 
JOURNAL OF SECURITY AND SUSTAINABILITY ISSUES

ISSN 2029-7017 print/ISSN 2029-7025 online

Economic 19(46): 772-772.

Strielkowski, W.; Tumanyan, Y.; Kalyugina, S. 2016. Labour Market Inclusion of International Protection Applicants and Beneficiaries, Economics and Sociology 9(2): 293-302. https://doi.org/10.14254/2071-789X.2016/9-2/20

Torój, A. 2017. Managing external macroeconomic imbalances in the EU: the welfare cost of scoreboard-based constraints. Economic Modelling 61:293-311. https://doi.org/10.1016/j.econmod.2016.10.009

UN. 2001. Replacement Migration: Is It a Solution to Declining and Ageing Populations? United Nations.

WEF. 2009. The Global Competitiveness Report 2009-2010. World Economic Forum.

WEF. 2015. The Global Competitiveness Report 2014-2015. World Economic Forum.

WEF. 2017. The Global Competitiveness Report 2016-2017. World Economic Forum.

Workie Tiruneh, M. et. al. (2012). Predvídanie potrieb trhu práce v SR: Teoretické východiská a empirické výsledky. EKONÓM.

World Bank. 2017. Refugee Population by Country or Territory of Asylum. World Bank Group.

Peter Čajka https://orcid.org/0000-0003-0568-394X

Barbora Olejárová https://orcid.org/0000-0002-1109-9830

Andrea Čajková https://orcid.org/0000-0002-5951-1281 